\title{
INVESTIGATING THE PRODUCTION OF BIODIESEL FROM ALPHONSO MANGO SEED OIL
}

\author{
O. R. Momoh ${ }^{1}$, H. I. Audu ${ }^{2}$ and Z. B. Binta ${ }^{3}$

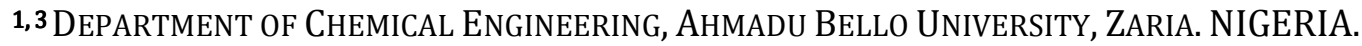 \\ 2 NATIONAL RESEARCH INSTITUTE OF CHEMICAL TECHNOLOGY, (NARICT), BASAWA, ZARIA. NIGERIA. \\ Email addresses:1 omuyar2002@yahoo.com,2auduharunaidowu@yahoo.com,3bzakari@gmail.com
}

\begin{abstract}
Alphonso Mango seed oil was investigated as a feedstock to determine some of the suitable parameters such as reaction temperature, time of reaction and oil to methanol ratio, that are suitable for biodiesel production. The preliminary investigation of the oil was carried out to determine the acid value from which the percentage free fatty acid (\%FFA) was calculated. The acid value and \%FFA were 35.90 and $17.95 \mathrm{mg} \mathrm{KOH/g}$ respectively. This necessitated a three steps esterification of the oil sample for reduction of the \%FFA to $0.547 \mathrm{mgKOH} / \mathrm{g}$ and later transesterification of the oil. The effect of reaction temperature, reaction time and oil to methanol ratio on production of biodiesel from the oil was then investigated. Optimum yield of biodiesel from this oil were obtained at ${ }^{60} \mathrm{C}$, 60mins (1 hour) and at 1:4 of oil to methanol ratio. The important properties of the biodiesel like the flashpoint, cetane number, kinematic viscosity, Iodine value, density and saponification value were determined and they were found to be $146^{\circ} \mathrm{C}, 76,3.6 \mathrm{~mm}^{2} / \mathrm{s}, 29.46 \mathrm{mEq} / \mathrm{g}, 0.87 \mathrm{~g} / \mathrm{cm}^{3}$ and $145.15 \mathrm{mgKOH} / \mathrm{g}$ respectively. The various values obtained were compared with specifications of ASTM D6751 standard and established that the Alphonso mango seed oil methyl ester could be used as an alternative to/or blended with petrodiesel.
\end{abstract}

Keywords: Alphonso mango seed, Esterification, Transeterification, Flashpoint, Cetane number, Viscosity, Saponification value

\section{INTRODUCTION}

The demand for fossil fuel is increasing very rapidly and with the current rate of consumption it is estimated that the remaining world reserves will be exhausted by the year 2051 [1]. Due to these factors, there is an urgent need to seek for an alternative energy especially renewable to fulfill the world's insatiable demand for energy and can replace petroleum-based fuel which has a great negative impact on the environments. In the current tide, one of the most popular alternative energy sources is the use of biomass which account for $4 \%$ of the world total energy consumption [2].

Hence, the use of biomass as a new source of alternative liquid fuel has attracted a lot of attention recently [3]. Biodiesel fuel is one example of biomass energy and it is generally made of methyl esters of fatty acids produced by the transesterification reaction of triglycerides with methanol with the help of a catalyst. Alcoholysis or transesterification of vegetable oils produces such fatty acids alkyl esters [4].

A lot of efforts have been made to determine the best optimum condition for the production of the fatty acid alkyl esters (FAAEs or Biodiesels). Hence this research is to investigate the optimum variables suitable for the production of biodiesel from Alphonso mango seeds oil using this method.

\section{BACKGROUND}

This section covers the overview of the Alphonso Mango plant viz its nature, habitat, the extraction of the oil and as suitable feedstock for the production of Biodiesel. Similarly, the general knowledge of the properties (temperature, reaction time, oil to methanol ratio, etc.) and standard specifications that are required of biodiesel production is discussed.

\subsection{The Alphonso Mango Plant}

Manigiferaindica- is the only mango tree commonly cultivated in many tropical and subtropical regions 
and its fruit is distributed essentially world-wide [5]. The Alphonso mango fruit that was used in this research belong to this specie.

The plant originated from south west Asia where it has been grown for over 4000 years. Over the years, this mango has spread to many parts of the tropical and sub-tropical world where the climate allows it to grow best. Their trees are evergreen that will grow to 60 feet tall and bear fruits 4 to 6 year after planting. Alphonso mango trees require hot, dry periods to set and produce good fruits [5]. Its propagation is usually by in-arching shield budding or grafting and may be grown from seeds. Budded trees fruit mature in 4-5 years. According to [6], the other different varieties include Botawi, Dodo, Apple, Davis, Smith, etc.

The fruits of Alphonso mango consist of the juicy portion and stone. The stone consists of shell and kernel. The shell is used as fuel in countries like India while the kernel is used for making starch, cattle feed etc. The kernel consists of carbohydrate $70 \%$, fats $15 \%$ and protein $5 \%$, while calcium and phosphorous make up the remaining. Typical outlook of its tree and fruits is depicted in Figure1.

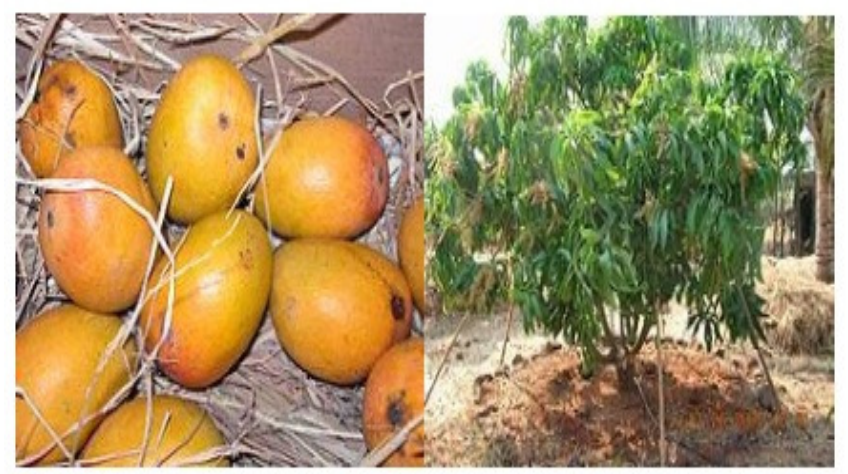

Figure 1: Alphonso mango tree and fruits

\subsection{Methods of Oil Extraction}

Usually, fats and oil may be recovered from oil bearing tissues by three methods with varying degree of mechanical simplicity. The methods are rendering, pressing and the use of solvent [7]. In this research work, despite its inherent disadvantages [8], the last method was employed in the extraction of the oil from the mango seed. According to [7], this is because the extraction rates are usually higher than from other methods and the oil in the residue is normally less than $2 \%$. For seed (such as Mango seed) which contain only about $5-15 \%$ of oil, it is not possible by expelling to reduce the oil content of the cake below $2 \%$ without thermal degradation occurring.

\subsection{Biodiesel}

Biodiesel refers to a vegetable oil or animal fat-based diesel fuel consisting of long chain alkyl (methyl, propyl, or ethyl) esters. Biodiesel is typically made by chemically reacting liquid (e.g., vegetable oil, animal fat (tallow) with an alcohol.

It must be stated that in the presence of catalyst like $\mathrm{KOH}$, saponification (soap production) process which proceeds in the same way like transesterification might be inherent in the production of biodiesel. On this account, it is very compulsory, that the amount of FFA\% must be reduced to the barest minimum. See Equations (1a) to (1c) for the transesterification process.

$$
\begin{gathered}
\text { Triglycerides }(\mathrm{TG})+\mathrm{R}^{\prime} \mathrm{OH} \\
\leftrightharpoons \text { Diglycerides + R'COOR1 } \\
\begin{aligned}
\text { Diglycerides }+ & \mathrm{R}^{\prime} \mathrm{OH} \\
\leftrightharpoons & \text { momoglycerides } \\
+ & \mathrm{R}^{\prime} \mathrm{COOR} 2 \\
\text { Monoglycerides } & +\mathrm{R}^{\prime} \mathrm{OH} \\
& \leftrightharpoons \text { Glycerol }+\mathrm{R}^{\prime} \mathrm{COOR} 3
\end{aligned}
\end{gathered}
$$

Blends of biodiesel and conventional hydrocarbonbased diesel are products most commonly distributed for use in the retail diesel fuel marketplace. It may be rated as B100, B20, B5, etc. In essence the "B" factor is used to state the amount of biodiesel in any fuel mix. Blends of less than $20 \%$ biodiesel can be used in diesel equipment with no, or only minor modifications.

\subsection{Parameters Affecting the Transesterification Process}

There are number of factors affecting the production of biodiesel. These factors include moisture and free fatty acid contents, reaction time, reaction temperature, molar ratio of alcohol to oil and type of alcohol, type and amount of catalyst, mixing intensity and co solvent [9]. These factors or variables usually have different effect on the transesterification process depending on the method. Despite the fact that the research focus is mainly concerned about the investigation of these parameters, they won't be discussed here for lack of space. However, interested readers are hereby referred to [10].

\section{MATERIALS AND METHODOLOGY}

This section briefly discusses the major sets of equipment, materials and experimental procedures that have direct bearing on the outcome of the research work. 


\subsection{Equipment}

The major sets of equipment as well as their specifications that are used in the work are briefly presented in Table 1.

Table 1: Major Sets of Equipment Employed in the Research

\begin{tabular}{|c|c|c|c|}
\hline $\mathrm{S} / \mathrm{N}$ & Equipment & Specifications & $\begin{array}{l}\text { Year and } \\
\text { place of } \\
\text { Manufacture }\end{array}$ \\
\hline 1 & $\begin{array}{l}\text { Weighing } \\
\text { Balance }\end{array}$ & $\begin{array}{l}\text { Model GT: Series } \\
\text { No 1027, 400V and } \\
\text { 500grammes }\end{array}$ & 2005, USA. \\
\hline 2 & $\begin{array}{l}\text { Magnetic } \\
\text { stirrer with } \\
\text { hotplate }\end{array}$ & $\begin{array}{l}\text { Speed range: } 100- \\
1000 \text { rpm, temp. } \\
\text { range: } 5-380^{\circ} \mathrm{C} \text {, } \\
\text { Electric supply: } \\
230 \mathrm{~V} \text { (DC),50HZ } \\
\text { single phase }\end{array}$ & $\begin{array}{l}1999, \\
\text { Gallenkamp, } \\
\text { Hungary }\end{array}$ \\
\hline 3 & Viscometer & $\begin{array}{l}\text { Model: NDJ-85. } \\
\text { Speed range: } 0.1- \\
\text { 100rpm. }\end{array}$ & 2003, USA. \\
\hline 4 & $\begin{array}{l}\text { Pensky- } \\
\text { Martens } \\
\text { flash point } \\
\text { tester }\end{array}$ & $\begin{array}{l}\text { Temp. range: } 0- \\
400^{\circ} \mathrm{C} \text {. }\end{array}$ & $\begin{array}{l}2000, \\
\text { England }\end{array}$ \\
\hline
\end{tabular}

\subsection{Specifications of the Material/Reagents:}

The materials/reagents used in this work such as ethanol, propan-2-ol (iso-propyl alcohol), $\mathrm{H}_{2} \mathrm{SO}_{4}$, nhexane, $\mathrm{KOH}$ and phenolphthalein were of analytical grade of BDH (England) and Qualikems (India) Laboratory Reagents. Distil water was used throughout.

\subsection{Methodology}

The methods that were employed throughout this work were anchored on standard procedures for tasks such as:

\subsubsection{Material collection}

The material collection involved the sourcing of the mango seeds, the oil extraction, and n-hexane recovery using Soxhlet Apparatus and finally, the determination of the optimum parameters and properties of the oil for its suitability for biodiesel production.

3.3.1.1 The source of the mango seeds: The large cultivation Alphonso mango seeds were collected from a school premises at Iyamoye, Ijumu in Kogi State, Nigeria. It was sundried, grinded using pestle and mortar and sieved to obtain a particle size diameter of $<1 \mathrm{~mm}$.
3.3.1.2 Extraction and recovery of n-hexane using soxhlet apparatus for the oil: The exercises were conducted by following the standard procedures as employed in [11].

3.3.1.3 Preliminary analysis of the mango seed oil: The preliminary works that were undertaken after extraction ranged from determination of the \%FFA, saponification and iodine values to the density of the oil. All these properties were carried out using ISO 3667, 1988 standard procedures. Similarly, the esterification of the oil in order to reduce the \%FFA was done by employing [5] methods.

\subsubsection{Determination of the \%FFA:}

$$
\begin{aligned}
& \text { Acid Value A.V } \\
& =\frac{\text { Titre value } \times 0.1 \mathrm{M} \mathrm{KOH} \times 56.1}{\mathrm{~m}} \\
& \% \text { Free Fatty Acids }(F F A)=\frac{A V}{2}
\end{aligned}
$$

In (2) and (3), $\mathrm{C}$ is the concentration of $\mathrm{KOH}, \mathrm{m}$ is the mass of the sample and $\mathrm{V}$ is the volume of $\mathrm{KOH}$

$$
\begin{aligned}
& \text { 3.3.1.5 Determination of saponification value } \\
& \qquad S V=\frac{\left(V_{0}-V_{1}\right) \times C \times 56.1}{m}
\end{aligned}
$$

In (4), $\mathrm{V}_{0}$ is the volume of $0.5 \mathrm{M}$ of hydrochloric acid used for blank test, $\mathrm{V}_{1}$ is the volume of $0.5 \mathrm{M}$ of $\mathrm{HCl}$ solution used for determination, and $\mathrm{C}$ is the exact concentration of $\mathrm{HCl}$

\subsubsection{Determination of Iodine value}

$$
I V=\frac{\left(\mathrm{V}_{1}-\mathrm{V}_{2}\right) \times \mathrm{C} \times 12.69}{\mathrm{~m}}
$$

In (5), $\mathrm{C}$ is the exact concentration of sodium thiosulphate used, $V_{1}$ and $V_{2}$ are the initial and final volumes of the sodiumthiosulphate respectively used and $m$ is the mass of the oil used

3.3.1.7 Esterification procedure: Reduction of the FFA content of the oil was carried out by esterification reaction using acid $\left(\mathrm{H}_{2} \mathrm{SO}_{4}\right)$ as catalyst. In the raw oil sample the initial value of FFA was $17.95 \%$.

\subsubsection{Transesterification}

During the transeterification of the oil for methyl ester (biodiesel) production, effect of temperature, contact time and oil to methanol ratio were investigated. The standard procedures as reported by [6] were employed. The results are recorded in the Section 4. 


\subsubsection{Analysis of the biodiesel from Alphonso mango seed oil}

Purified biodiesel obtained from the above procedures was characterized to test the following properties such as the density, saponification and iodine values, cetane number, flash point and viscosity. Similarly, the standard procedures as recommended by [11] were employed. The results are displayed in section 4 .

\section{RESULTS AND DISCUSSION}

\subsection{Results}

The percentage FFA of the oil before and after the process of esterification is as presented in Tables 2 and 3.

Table 2: Percentage FFA of the Mango Seed Oil before Esterification

\begin{tabular}{lc}
\hline Properties/Units & Values \\
\hline Acid value, mgKOH/g & 35.90 \\
Free fatty acid (FFA), mgKOH/g & 17.95 \\
\hline
\end{tabular}

Table 3: Percentage FFA of the Mango Seed Oil after Esterification

\begin{tabular}{llll}
\hline Properties & $\begin{array}{l}\text { First titre } \\
\text { value } \\
\text { (Average) }\end{array}$ & $\begin{array}{l}\text { Second } \\
\text { titre value } \\
\text { (Average) }\end{array}$ & $\begin{array}{l}\text { Third titre } \\
\text { value } \\
\text { (Average) }\end{array}$ \\
\hline $\begin{array}{l}\text { Acid Value, } \\
\mathrm{mgKOH/g}\end{array}$ & 8.13 & 5.05 & 1.094 \\
$\begin{array}{l}\text { Free Fatty } \\
\text { Acid, } \%\end{array}$ & 4.07 & 2.525 & 0.547 \\
\hline
\end{tabular}

Figures 3, 4 and 5 represent the graphs obtained in the three parameters investigated in the work.

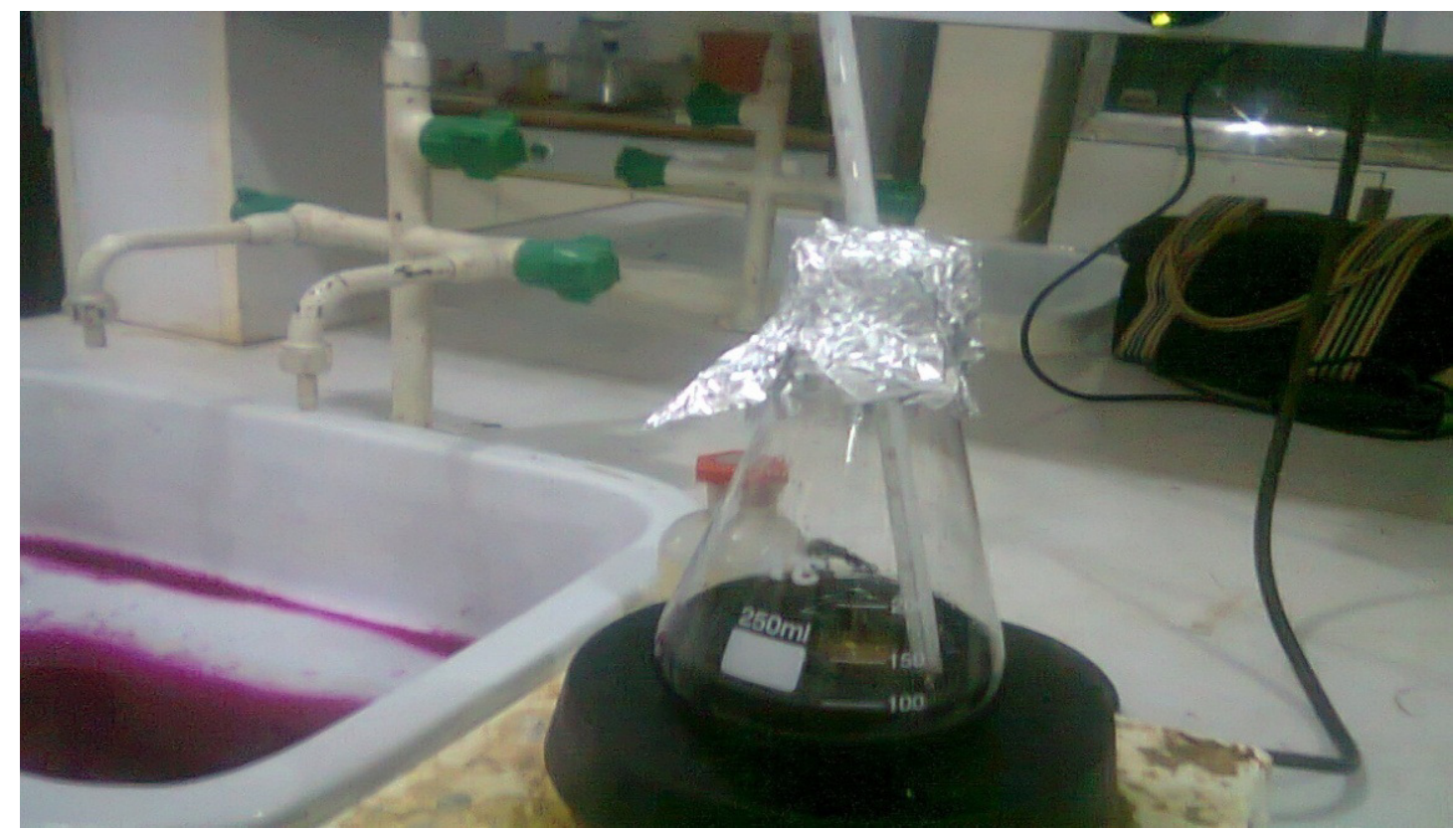

Figure 2: The Esterification/Transesterification Process Setup

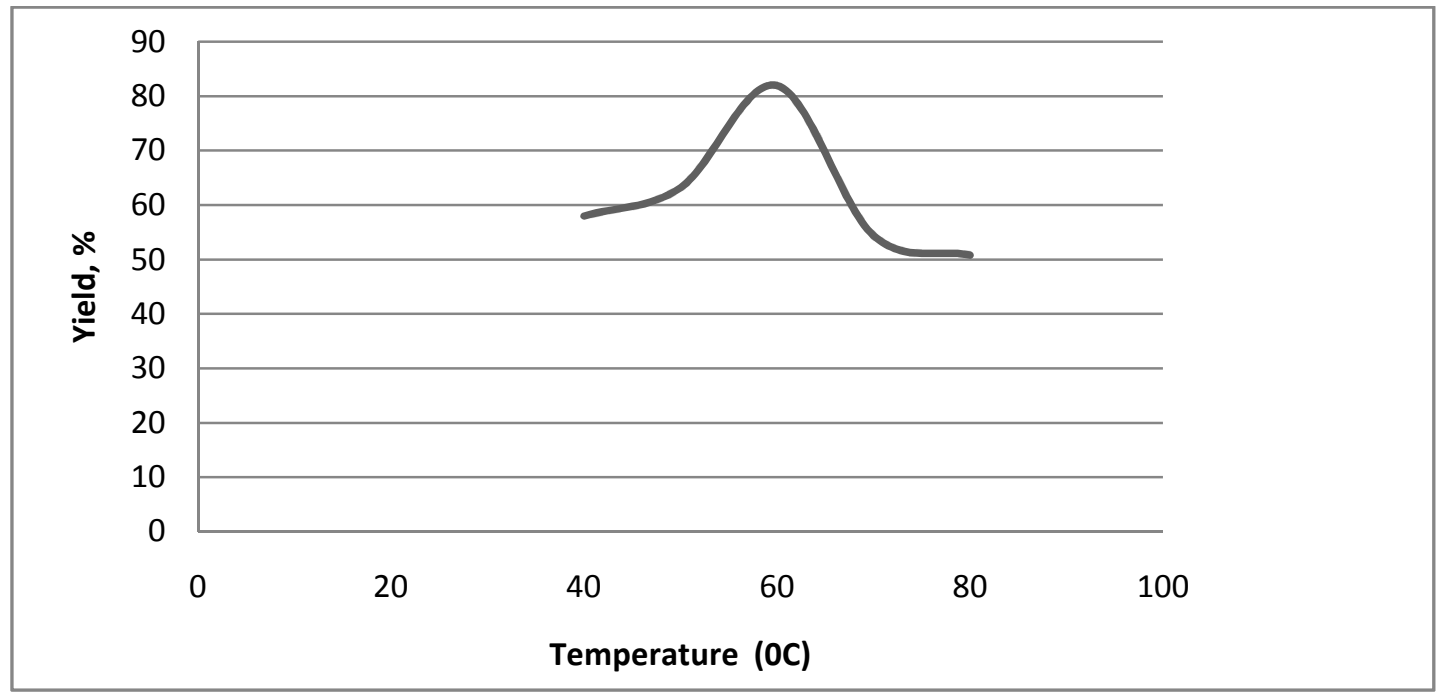

Figure 3: Profile of Effect of Temperature on the Transesterification of the oil 


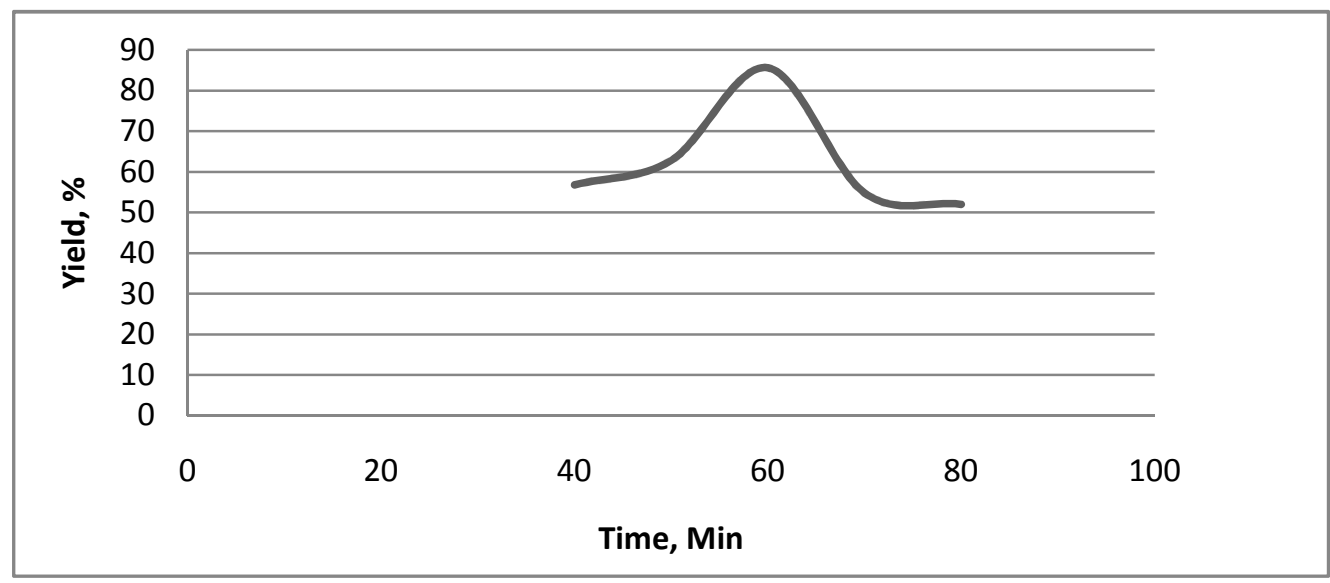

Figure 4: Profile of Effect of Time on the Transesterification of the oil

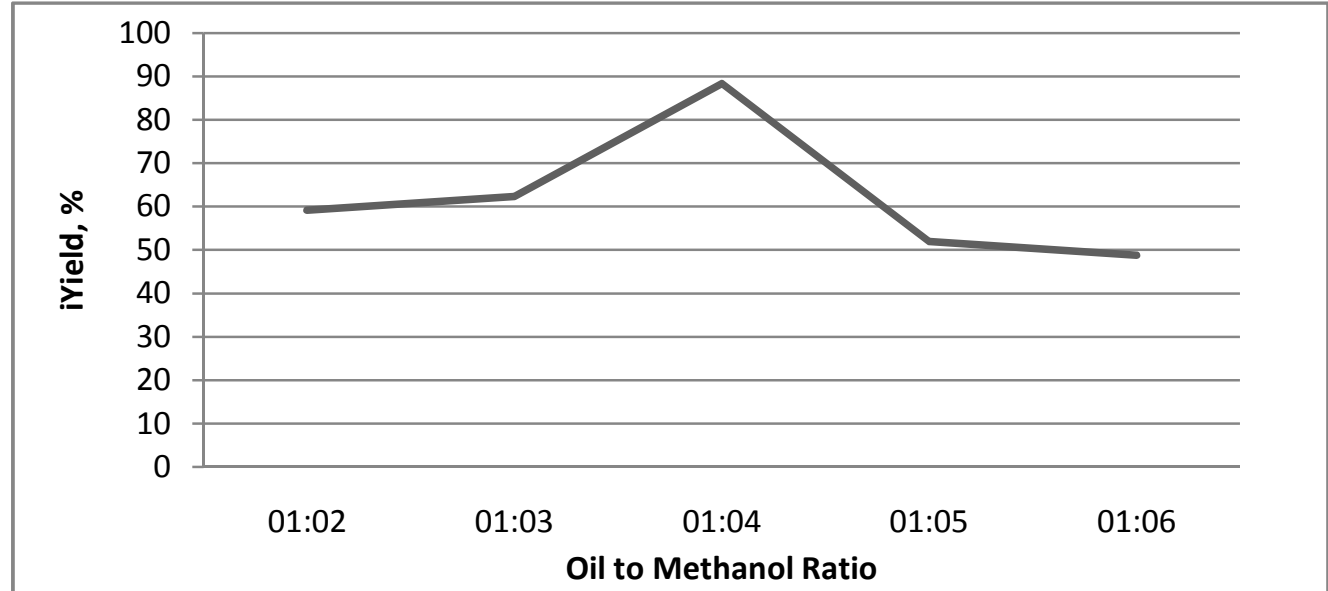

Figure 5: Profile of Effect of Oil to Methanol Ratio on the Transesterification of the oil

Table 4: Properties of the Biodiesel from the Mango Seed soil

\begin{tabular}{lcc}
\hline Properties & Biodiesel & Standard \\
\hline Saponification value, $\mathrm{mgKOH} / \mathrm{g}$ & 145.15 & - \\
Iodine value,mEqiodine/g & 29.46 & - \\
Cetane number & 76 & 47, minimum \\
Density, $\mathrm{g} / \mathrm{cm}^{3}$ & 0.87 & $0.86-0.90$ \\
Flash point, ${ }^{0} \mathrm{C}$ & 146 & $130^{\circ} \mathrm{C}$, minimum \\
Kinematic viscosity, $\mathrm{mm}^{2} / \mathrm{s}$ & 3.6 & $1.9-6.0$ \\
\hline
\end{tabular}

\subsection{Discussion of Results}

In this section, most of the sets of data (Charts and Tables) that were generated in the cause of carrying out this research work are discussed. The results and/or problems would be interpreted by trying to speculate it in terms of cause and effect phenomenon.

\subsubsection{Properties of the mango seed oil before and after esterification}

According to [12], one of the most important parameters usually used to justify the suitability of oil for biodiesel production, after its esterification is the $\%$ FFA. In this case, from Tables 2 and 3, the acid value cum $\% \mathrm{FFA}$ has finally met the required specification of $0.5 \%$.

\subsubsection{Saponification and iodine values}

From the result obtained before and after esterification of the oil $(193.55 \mathrm{mgKOH} / \mathrm{g}$ and $145.15 \mathrm{mgKOH} / \mathrm{g}$ ) respectively, the saponification values are high. Therefore, there is possibility of the oil to form soap during transesferification. Nevertheless the values were almost the same when compared with that obtained from African bush mango [7]. 
From Table 2 and 3, it was observed that the iodine values for the raw oil and esterified one were 33.25 and $29.46 \mathrm{mEq} / \mathrm{g}$ respectively thereby confirming that Alphonso mango seed oil is highly saturated, thus solid at ambient temperature. From the research carried out on African bush mango, the value obtained was $86.166 \mathrm{mEq} / \mathrm{g}$, necessitating the three-stage esterification that was carried out before transesterification process as earlier stated.

From Table 4 the other parameters such as the cetane number, density, flash point and the kinematic viscosity which were $76,0.87 \mathrm{~g} / \mathrm{cm}^{3}, 146^{\circ} \mathrm{C}$ and $3.6 \mathrm{~mm}$ $2 /$ s compare favorably with [13] standard. It is hopeful that the biodiesel can be blended with the conventional one for diesel fuel in automobiles.

\subsubsection{Effect of temperature, reaction time and oil to methanol ratio on the biodiesel yield}

4.2.3.1 Effect of temperature: Fixing the oil to methanol ratio of $1: 4(\mathrm{v} / \mathrm{v}), 60$ min of reaction time, which were the corresponding parameters for the highest yield and $1 \%$ triglyceride weight of catalyst, the varying temperatures of $40,50,60,70$ and $80^{\circ} \mathrm{C}$ were investigated.

It is observed that from Figure 3 , at $40^{\circ} \mathrm{C}$, the yield is low (58\%). This is probably due to the fact that the methanol is at subcritical state and its solubility is not close to that of oil. At $60^{\circ} \mathrm{C}$, the yield was high, $82 \%$. This is due to the formation of a single phase between oil and methanol. This result was in agreement with the result obtained by [12]. At $80^{\circ} \mathrm{C}$, the yield is very poor because the saturated and unsaturated fatty acid easily undergoes side reaction such as thermal decomposition and dehydrogenation.

\subsubsection{Effect of reaction time}

The parameters were again fixed as stated in the previous section and a varying time of reaction of 40 , 50, 60, 70 and 80 minutes.

From Figure 4, the yield at 40 minutes is low due to the incomplete reaction while at 60 minutes highest yield of biodiesel was obtained because of single phase formation between oil and methanol. The yield was low at the reaction time of 80 minutes because of the longer time of reaction which enhances the hydrolysis of esters which result to loss of esters and causes more fatty acid to form soap.

\subsubsection{Effect of oil to methanol ratio}

Figure 5 presents the result of oil-to-methanol ratio. The parameters were equally fixed as before and varying oil to methanol ratio as 1:3, 1:3.5, 1:4, 1:4.5 and 1:5. At ratio 1:3, the yield was poor because the methanol used was probably insufficient. It is highest at ratio 1:4 due to the proper mixing of the oil and methanol. This is contrary to most literature sources which reported highest yield in the region of 1:6 oil to methanol ratio. This may necessitate the need for further investigation into the properties and composition of Alphonso mango seed oil. The yield decreased from 1:.4,5, i.e., a higher ratio because of difficulties in separating excess methanol from biodiesel and glycerol [5].

\section{CONCLUSIONS}

This research work has clearly demonstrated that Alphonso mango seed oil can be used as a feed to produce high quality methyl ester (biodiesel).

Similarly the properties of the biodiesel such as Saponification value of $145.15 \mathrm{mgKOH} / \mathrm{g}$, Iodine value (29.46mEqiodine/g), Cetane number (76), Density $\left(0.87 \mathrm{~g} / \mathrm{cm}^{3}\right)$, Flash point $\left(146{ }^{\circ} \mathrm{C}\right)$ and Kinematic viscosity of $3.6 \mathrm{~mm}^{2} / \mathrm{s}$ produced from the Alphonso mango seed oil all fall within the standard as stated in [13] and [14].

It was equally established from the work that the optimum parameters at which high yield of biodiesel can be achieved is at temperature of $60^{\circ} \mathrm{C}$, reaction time of 1 hour and oil to methanol ratio of 1:4.

Finally, production of biodiesel from Alphonso mango seed oil could drastically reduce environmental pollution that can be caused by their fruits.

\section{REFERENCES}

[1] Momoh O.R. "World Energy Reserves". Enhancing Light-ends Recovery through Joint Atmospheric Distillation of Heavy Crude and Used Engine Oil. Ph.D Dissertation. Department of Chemical Engineering, Ahmadu Bello University, Zaria.Nigeria, 2011, p.14.

[2] http://en.wikipedia.org/wiki/File:World energy usage width chart.svg(accessed 23/2/2010).

[3] Warabi Y, Kusdiana D and Saka S. "Reactivity of triglycerides and fatty acids of rape seed oil in supercritical alcohol". Journal of Bioresource Technology,Vol. 91, 2004, pp 283-87.

[4] Selmi B. and Thomas D. "Immobilized lipasecatalyzed ethanolysis of sunflower oil in a solvent". Free Medium journal of American Oil Chemist Society, Vol. 75, 1998, pp 691-695.

[5] Gerhard, G.J., Jurgen, K. and Van K. Handbook of Biodiesel, AOCS Press Champaign Illinois, USA, 2005. 
[6] Meda C.S., Venkata R.M., Mallikarjunand M.V. and Vijaya K.R. "Production of Biodiesel from Neem Oil". Int. J. Eng. Studies, 1(4), 2009, pp 295-302.

[7] Antony R,S. Robinson S., Lindon D.S. and Robert L.C. " Biodiesel Production from Jatropha Oil and its characterization". School of Mechanical Sciences, karunya University, Coimbatore, India, 2009.

[8] Castro M.D.L. and Ayuso L.E.G. "Soxhlet extraction of solid materials", Analytical chimica Acta,Vol. 369 (12), 1998, pp 1-10.

[9] Demirbas A,. Biodiesel fuels from vegetable oils via catalytic and Non-catalytic supercritical alcohol by transesterification and other methods. Manag 44: 2003, pp 2093- 2109.

[10] Audu H.I. Investigating the Optimum Parameters for the Production of Biodiesel from Alphonso Mango Seed Oil. Unpublished PGD thesis. Department of
Chemical Engineering, Ahmadu Bello University, Zaria. Nigeria. 2012, pp.1-59.

[11] Gerpen, J.V. Biodiesel Handbook, Department of Mechanical Engineering, Iowa State University Ames, Iowa, U.S.A., 2005.

[12] Mehler L.C., Sager D.V. and NaiK S.N. "Technical aspects of biodiesel production by transesterification". Energy Review 10, 248 - 268, 2006.

[13] ASTM D6751. "Biodiesel standard." United State of America Biodiesel National Board, American Journal of Applied Sciences 6 (7), 2008, pp 1390-1395.

[114] Nwakaire J.N. and Durugu S. "Determination of Physico-chemical Properties of Oleander Seed Oil for Biodiesel Production". Nigerian Journal of Technology. Vol. 32, No.3, 2013, pp. 440-442. 